\title{
Evaluation of embryo collection and transfer days on pregnancy rate of Mangalarga Marchador mares during the breeding season
}

Evaluación de los días de recolección y transferencia de embriones sobre las tasas de preñez en yeguas Mangalarga Marchador durante la estación de monta

\begin{abstract}
Avaliação do dia da colheita e da transferência de embriões equino da raça Mangalarga Marchador durante a estação de monta
\end{abstract}

José C Ferreira-Silva $^{l}$; Felipe A B M Sales ${ }^{l}$; Pábola S Nascimento ${ }^{l}$; Marcelo T Moura ${ }^{l}$; Leopoldo M Freitas-Neto ${ }^{l}$; Jorge M Rocha $^{2}$; Heder N Ferreira ${ }^{3}$; Marcos A L Oliveira ${ }^{l}$.

\footnotetext{
${ }^{1}$ Laboratório de Biotécnicas Reprodutivas, Departamento de Medicina Veterinária, Universidade Federal Rural de Pernambuco, Recife-PE, Brasil.

${ }^{2}$ Universidade Federal do Rio Grande do Norte, Natal-RN, Brasil.

${ }^{3}$ Faculdade Pio Décimo - Hospital Veterinário, Aracaju-SE, Brasil.
}

(Received: December 1, 2017; accepted: November 17, 2018)

To cite this article:

Ferreira-Silva JC, Sales FABM, Nascimento PS, Moura MT, Freitas-Neto LM, Rocha JM, Ferreira HN, Oliveira MAL. Evaluation of embryo collection and transfer days on the pregnancy rate of Mangalarga Marchador mares during the breeding season. Rev Colomb Cienc Pecu 2019; 32(3):214-220. DOI: https://doi.org/10.17533/udea.rccp.v32n3a06

* Corresponding author: Av. Dom Manoel de Medeiros, s/n Dois Irmãos, CEP: 52171-900 Recife-PE, Brasil. Tel.: +55-081- 33206414. E-mail: ferreirasilva. jc@gmail.com 


\section{Abstract}

Background: Proper timing for embryo collection and transfer in horses -which is critical for the success of this biotechnology- is still debated. Additionally, there is little information on this technology under tropical conditions. Objective: To determine the best day for collection and transfer of embryos in Mangalarga Marchador mares under Brazilian northeast's conditions. Methods: Donors $(n=30)$ and recipients $(n=76)$ in diestrus phase were selected based on both clinical and gynecology examinations. Estrus was induced on both donor and recipient mares by intramuscular injection of 5 mg Dinoprost, aiming to obtain an ovulation interval of -1 to +3 between recipient and donor. Ovulation was induced with buserelin acetate when the largest follicle reached at least $35 \mathrm{~mm}$ in diameter. At this time, mares were subjected to artificial insemination at 48-hour intervals until ovulation. The embryos were collected on days 7, 8, and 9 after ovulation. Results: The embryo collection on day 8 was more efficient $(p<0.05)$ than on day 7 , but it was not more effective $(\mathrm{p}>0.05)$ than day 9 , which presented the same efficiency $(p>0.05)$ as day 7 . From a total of 76 embryos transferred to the recipients, that were between days 4 and 9 after ovulation, there was no influence $(\mathrm{p}>0.05)$ of the day of transfer on pregnancy rate. Conclusions: The embryo collection must be performed on day 8 after ovulation, and transfer can be performed on any day of that interval (4-9) without affecting the pregnancy rate.

Keywords: assisted reproduction; embryo; embryo collection; embryo recipients; embryo transfer; Equus caballus; estrous synchronization; Mangalarga Marchador; mare.

\section{Resumen}

Antecedentes: El momento mas apropiado para la recolección y transferencia de embriones en equinos -que es fundamental para el éxito de ésta biotecnología- continua siendo sujeto de estudio . Además, es escasa la información sobre ésta tecnología en condiciones tropicales. Objetivo: Determinar el momento mas adecuado para la recolecta y transferencia de embriones en yeguas Mangalarga Marchador, en las condiciones del nordeste Brasileño. Métodos: Donadoras $(n=30)$ y receptoras $(n=76)$ en la fase de diestro se seleccionaron con base en los exámenes clínicos y ginecológicos. El estro de las yeguas donadoras y receptoras fue inducido con $5 \mathrm{mg}$ de Dinoprost, vía intramuscular, intentando obtener un intervalo de ovulación de -1 a +3 entre la receptora y la donadora. La ovulación fue inducida con acetato de buserelina cuando el folículo mayor alcanzó $35 \mathrm{~mm}$ de diámetro. En ese momento, las yeguas fueron sometidas a inseminación artificial en intervalos de 48 horas hasta la ovulación. Los embriones fueron recolectados en los días 7, 8 y 9 después de la ovulación. Resultados: La recolecta de embriones en el día 8 fue más eficiente $(p<0,05)$ que en el día 7 , pero no fue más efectivo $(p>0,05)$ que en el día 9, el cuál presentó la misma eficiencia $(p>0,05)$ que en el día 7 . De un total de 76 embriones transferidos a las receptoras, que se encontraban entre el día 4 y 9 después de la ovulación, no se registró influencia $(\mathrm{p}>0,05)$ del día de la transferencia en la tasa de preñez. Conclusiones: La recolecta embrionaria debe ser realizada el día 8 después de la ovulación, y la transferencia puede ser realizada en cualquier día de este intervalo (4 a 9) sin que se afecte la tasa de preñez.

Palabras clave: colección de embriones; embrión; Equus caballus; Mangalarga Marchador; receptora de embriones; reproducción asistida; sincronización del estro; transferencia de embriones; yegua.

\section{Resumo}

Antecedentes: A importância do momentoda colheita e da transferência do embrião equino para o sucesso dessa biotécnica em equino continua sem ser completamente entendida. Adicionalmente, existe pouca informação sobre essa tecnologia em condições tropicais. Objetivo: Determinar o melhor dia para colheita e para transferência de embriões em eguas manga larga marchador nas condições do nordeste brasileiro. Métodos: Doadoras $(n=30)$ e receptoras $(n=76)$ na fase de diestro foram selecionadas com base nos exames clínico e ginecológicos. O estro das éguas doadoras e receptoras foi induzido com $5 \mathrm{mg}$ de Dinoprost administrado por via intramuscular, buscando obter um intervalo de ovulação de -1 a +3 entre a receptora e a doadora. A ovulação foi induzida com acetato de buserelina quando o foliculo maior alcançou o tamanho de $35 \mathrm{~mm}$ de diâmetro. Nesse momento, as éguas foram submetidas a inseminação artificial em intervalos de 48 horas até a ovulação. Os embriões foram colhidos nos dias 7, 8 e 9 depois da ovulação. Resultados: A colheita de embriões no dia 8 foi mais eficiente $(p<0,05)$ do que no dia 7 , porem não foi mais efetivo $(p>0,05)$ do que o dia 9 , o qual apresentou a mesma eficiência $(p>0,05)$ que o dia 7 . De um total de 76 embriões transferidos para as receptoras que se encontravam entre os dias 4 e 9 depois da ovulação, não se registrou influência $(p>0,05)$ do dia da transferência sobre a taxa de prenhez. Conclusões: A colheita embrionária deve ser realizada no 
dia 8 depois da ovulação, e a transferência pode ser realizada em qualquer dia desse intervalo (4-9) sem que a taxa de prenhez seja afetada.

Palavras-chave: colheita de embriões; egua; embriões; Equus caballus; Mangalarga Marchador; receptoras de embriões; reprodução assistida; sincronização do estro; transferência de embriões.

\section{Introduction}

Embryo transfer (ET) biotechnology in horses is a useful tool for allowing rapid genetic dissemination of valuable animals (Arruda et al., 2001; Azevedo et al., 2015). The ET makes it possible to obtain foals from aged mares, mares with problems to maintain gestation, and mares under training or competition. This biotechnology also allows obtaining foals of young mares ( 1 to 2 years) without impairing its development and shortens the generation interval of mares with a promising pedigree (Sieme et al., 2018).

The ET technology is less complex than other reproductive biotechnologies, such as in vitro embryo production (Lira et al., 2009; Claes et al., 2016; Sanchez et al., 2016; Rua et al., 2016). Its efficiency depends on proper selection and management of mares (Squires et al., 1999; Vanderwall, 2008), and estrus and ovulation synchrony (Iuliano et al., 1985; Taveiros et al., 2003/2008; Rabelo et al., 2009; Hinrichs, 2012; Azevedo et al., 2014).

Equine embryos are transported from the oviduct to the uterus from the compact morulae to the blastocyst stages, between the 5th and 6th days after ovulation (Oguri and Tsutsumi, 1972). Embryos obtained by post-ovulation artificial insemination (AI) reach the uterus later compared to their counterparts obtained by pre-ovulation AI, possibly due to delayed fertilization (Bertani et al., 1997). Therefore, embryo collections should be performed around 12 hours after day 7 (Day 7.5) and should not exceed day 8 (CuervoArango et al., 2009).

The most appropriate day for embryo collection remains controversial. On one hand, for collections between days 6 and 9 after fertilization, collections made between days 7 and 8 retrieved greater embryo numbers (Cuervo-Arango et al., 2009; Sieme et al., 2018). On the other hand, similar embryo recovery rates could be achieved from days 5 to 8 postovulation (Vogelsang et al., 1985). Also, according to Squires and Seidel (1995), day 6 is the most advantageous for embryo cryopreservation, and day 9 -although less used for ET- shows lower results in comparison to days 7 and 8 .

The ET into previously synchronized mares can be performed by either surgical or transcervical methods (Fleury et al., 2001). Despite ongoing controversy, the most frequently used period for ET has been from days 5 to 9 after donor ovulation (Iuliano et al., 1985; Vogelsang et al., 1985; Fleury et al., 2001; Hajčić et al., 2008; Sieme et al., 2018).

Given that day for collection and ET in horses plays a crucial role in its overall success, a limited number of reports on the subject under the Brazilian northeast condition are available. The northeast of Brazil is a semi-arid region that in spite of stable luminosity throughout the year, faces substantial variation in forage supply due to low and uneven distribution of rainfall. The breeding season spans from September to March, which is during the dry season. Therefore, the objective of this study was to define the most appropriate days for collection and transfer of embryos in Mangalarga Marchador mares under Brazilian northeast's conditions.

\section{Material and Methods}

\section{Ethical considerations}

The study was approved by the Ethics Committee for Animal Research at Universidade Federal Rural de Pernambuco (License: 011/2013).

\section{Location and animals}

The experiment was conducted in Limoeiro (Pernambuco state, Brazil). The farm is located at the following geographic coordinates, $7^{\circ} 52$ ' 29' $\mathrm{S}$ latitude and $35^{\circ} 27^{\prime} 01^{\prime \prime} \mathrm{W}$ longitude. Mean annual temperature is $24.6{ }^{\circ} \mathrm{C}$ and mean total rainfall is $1,007 \mathrm{~mm}^{3}$. 
Mangalarga Machador donor and recipient mares were pluriparous, non-lactating, aged between 5 and 15 years, and body weight ranged from 450 to $550 \mathrm{~kg}$. All mares were raised under semi-extensive conditions, mostly grazing on cultivated pastures (Digitaria decumbes) with access to water and mineralized salt (Suprafós 73, Supranor ${ }^{\circledR}$, Recife, PE, Brazil) ad libitum. Mares were also supplemented with hay (Cynodon spp), alfalfa (Medicago sativa), and $4 \mathrm{~kg}$ /day of a pelletized commercial horse ration containing $16 \%$ crude protein, $12.0 \%$ fiber, 3,080 $\mathrm{kcal} / \mathrm{kg}$ fat, $1.3 \%$ calcium, $0.75 \%$ phosphorus, and 6.0\% ether extract (Corcel Reprodução, Presence, São Lourenço da Mata, PE, Brazil).

The body condition score of mares was between 5 and 7, in a 1 to 9 scale, as described by Henneke et al. (1983). Other factors considered for selection were: reproductive performance, clinical condition, and gynecological examination by ultrasonography for identification of uterine fluid and endometrial alterations that could compromise fertility, as suggested by Taveiros et al. (2008). For this examination, an Aquila Pro, Esaote, equipped with a linear multifrequency transducer ( 6 and $8 \mathrm{MHz}$ ) was used.

Estrus was induced in donors $(n=30)$ and recipients ( $\mathrm{n}=76$ ) with IM injection of $5 \mathrm{mg}$ Dinoprost $\left(\right.$ Lutalyse $^{\circledR}$, Pfizer, São Paulo, SP, Brazil), and a single estrous cycle was used per mare. This strategy was carried out to obtain an -1 to +3 ovulation synchronies between the recipient and donor ovulations, as proposed by Squires (1993). Ovulation was induced with buserelin acetate (Conceptal ${ }^{\circledR}$, MSD Saúde Animal, São Paulo, SP, Brazil) after the largest follicle had reached at least 35 mm diameter. At this time, mares were inseminated with fresh semen from a single stallion of proven fertility, using $500 \times 10^{6}$ viable sperm concentration in 48-hour intervals until ovulation occurred, as recommended by Rabelo et al. (2009).

Embryo collections were performed on days 7 (D7), 8 (D8), and 9 (D9) post- ovulation (single embryo collection per mare). The procedure was carried out by the open method, which requires the introduction of a catheter (Bivona, St. Paul, Minnesota, USA) into the uterus body to fixate the balloon to the uterine walls. A total of $3 \mathrm{~L}$ of Ringer-Lactate solution was used, divided into three fractions (Fleury and
Alvarenga, 1999). After the last uterine flushing, the balloon was emptied, and the catheter was removed. The filtered content was deposited in Petri dishes for embryo recovery using a stereomicroscope (80X), as suggested by Taveiros et al. (2008). Immediately after collection, donor mares received an additional Dinoprost injection to avoid an unwanted pregnancy.

After recovery, embryos were evaluated for the stage of development and graded based on their morphology, as described by McKinnon et al. (1993). Only grades I and II embryos $(n=76)$ were transferred immediately to recipients at various post-ovulation stages (D4, D5, D6, D7, D8, and D9). Pregnancy diagnosis was performed by ultrasonography on day 25 after ET. All ultrasonographic exams were carried out by the same technician.

\section{Statistical analysis}

The statistical analysis of binomial data was performed using a chi-square test with Yates correction (Preacher, 2001). The significance level of 5\% was used.

\section{Results}

Table 1 shows results relative to embryo collection at different days post-ovulation. Day 8 was more efficient than day 7 for embryo recovery $(p<0.05)$, but it did not differ with day $9(\mathrm{p}>0.05)$. Moreover, day 9 was not more efficient than day $7(\mathrm{p}>0.05)$, although showing a trend towards such a difference $(p$ $=0.061$ ). Regarding transferable embryos, there was no difference among the days of collection $(p<0.05)$.

Table 1. Influence of the day of the collection on embryo recovery (Positive) and morphological evaluation (Transferable) in Manga Larga Marchador donor mares.

\begin{tabular}{|c|c|c|c|}
\hline \multirow{2}{*}{$\begin{array}{c}\text { Collection } \\
\text { (Day) }\end{array}$} & \multicolumn{2}{|c|}{ Uterine flushing } & \multirow{2}{*}{$\begin{array}{c}\text { Transferable } \\
\text { embryos } \\
\text { n (\%) }\end{array}$} \\
\hline & $\begin{array}{c}\text { Total } \\
\text { (n) }\end{array}$ & $\begin{array}{c}\text { Positive } \\
\text { n (\%) }\end{array}$ & \\
\hline D7 & 21 & $9(42.8)^{A}$ & $6(66.6)^{A}$ \\
\hline D8 & 70 & $51(72.8)^{\mathrm{B}}$ & $39(76.4)^{\mathrm{A}}$ \\
\hline D9 & 59 & $39(66.1)^{\mathrm{AB}}$ & $31(79.4)^{\mathrm{A}}$ \\
\hline Total & 157 & $97(61.7)$ & $76(78.3)$ \\
\hline
\end{tabular}

Different superscript letters $(A, B)$ within the same column indicate significant difference $(p<0.05)$. 
Table 2 contains the results of pregnancy and conceptus loss about the recipients' post-ovulatory stage (in days) at the time of ET. There was no effect of recipient's post-ovulation day at ET on pregnancy rates and conceptus loss $(\mathrm{p}>0.05)$.

Table 2. Influence of the recipients' post-ovulatory stage (Day) on pregnancy rates in Manga Larga Marchador mares submitted to embryo transfer.

\begin{tabular}{lccc}
\hline \multicolumn{4}{c}{ Embryo Transfer } \\
\hline $\begin{array}{c}\text { Day } \\
\text { ovost- } \\
\text { ovulation) }\end{array}$ & $\begin{array}{c}\text { Embryos } \\
\text { (n) }\end{array}$ & $\begin{array}{c}\text { Pregnancy } \\
\mathbf{n}(\%)\end{array}$ & $\begin{array}{c}\text { Conceptus loss } \\
\mathbf{n}(\%)\end{array}$ \\
\hline D4 & 6 & $2(33.3)$ & $4(66.7)$ \\
D5 & 20 & $18(90.0)$ & $2(10.0)$ \\
D6 & 17 & $13(76.4)$ & $4(23.6)$ \\
D7 & 15 & $9(60.0)$ & $6(40.0)$ \\
D8 & 11 & $7(63.6)$ & $4(36.4)$ \\
D9 & 7 & $3(42.8)$ & $4(57.2)$ \\
\hline Total & $\mathbf{7 6}$ & $\mathbf{5 2 ( 6 8 . 4 )}$ & $\mathbf{2 4 ( 3 1 . 6 )}$ \\
\hline
\end{tabular}

\section{Discussion}

The equine embryo reaches the uterus between the fifth and sixth day after ovulation (Oguri and Tsutsumi, 1972; Webber et al., 1991). That is why the day of collection is described as an essential factor on quantity (Montechiesi, 2015) and quality of retrieved embryos (Betteridge et al., 2000; Allen, 2001). The studies mentioned above tested different days for embryo collection. While day 7 was the least preferable, these reports are in contrast to Vogelsang et al. (1985), Iuliano et al. (1985) and Fleury et al. (2001), who suggested day 7 as the most promising day for embryo collection. The most plausible explanation for this discrepancy is that embryos from Mangalarga Marchador mares at day 7 post-ovulation are smaller in size than other breeds, thus making their recovery more challenging during uterine flushing. Despite the embryo potential for adapting to unsynchronized uterine environments, it is probable that under such conditions, it may have initially faced slower development at gene, cellular, and tissue levels (Gibson et al., 2017).

The results described herein may further support that collection can be preferentially performed at day 8 , but can also be carried out at day 9 without diminishing embryo recovery. In a previous report, Iuliano et al. (1985) assumed that collections could be performed at day 8, while Fleury et al. (2001) supported that day 8 is the most promising day for embryo collection. Albeit the possibility that embryos at day 7 post-ovulation can be smaller than their day 9 counterparts, these later embryos are free from the zona pellucida and are more likely to succumb to mechanical damage during uterine flushing (Stout et al., 2005). Nevertheless, their morphological quality was similar, since the percentage of transferable embryos did not differ.

The ET in horses can be performed by surgical or transcervical methods into previously synchronized recipients (Fleury et al., 2001). Despite the controversy among reports on the best day for ET, it has been mostly described during days 5 to 9 after donor ovulation (Iuliano et al., 1985; Vogelsang et al., 1985; Fleury et al., 2001; Stout, 2006; Hajčić et al., 2008; Azevedo et al., 2015).

As described above, donor and recipient mare management, selection, ovulation synchrony, and -particularly- embryo quality for ET could have positively affected the results. This reasoning is based on the fact that pregnancy rates from day four to nine could be similar is ruled out. Thus, the remaining data would be in agreement with those published by several researchers (Wilson et al., 1987; McKinnon and Squires, 1988; Fleury et al., 2001; Taveiros et al., 2008).

Although the absence of statistical difference among pregnancy results, those obtained on days five and six can be outlined from the remaining. In spite of lack of scientific support for these days as the best time-points for ET, it is possible to account for this pregnancy data to the more extended period that embryos have to develop for maternal to fetal crosstalk in the uterus. This crosstalk, among other possibilities, can be in consequence of conceptus migration within uterine horns, thus inhibiting PGF2 $\alpha$ production and release (Conley, 2016).

Therefore, embryos transferred more precociously may not have acquired the necessary competency to promote the signaling above, since it is the exact 
moment of embryonic activation (Stout, 2006). It is possible that this problem overlaps with fluctuating P4 concentration during this time, and $\mathrm{P} 4$ available may not be sufficient for establishing uterine conditions to support embryonic development (Irvine et al., 2000).

In conclusion, equine embryos can be collected eight days post-ovulation, and their transfer can be performed in a relatively broad period without any detrimental effect on pregnancy rates.

\section{Acknowledgments}

Authors would like to acknowledge the Coordenação de Aperfeiçoamento de Pessoal de Nível Superior and Fundação de Amparo à Ciência e Tecnologia do Estado de Pernambuco for funding of this study. Assistance from Dr. Jeisane Accioly (Accioly Livestock Industry Services, Australia) with English review is also appreciated.

\section{Conflict of Interest}

The authors declare they have no conflicts of interest with regard to the work presented in this report.

\section{References}

Allen WR. Fetomaternal interactions and influences during equine pregnancy. Reproduction 2001; 121(4):513-527. http://www. reproduction-online.org/content/121/4/513.full.pdf + html

Arruda RP, Visintin JA, Fleury JJ, Garcia AR, Madureira EH, Celeghini ECC, Neto JRN. Existem relações entre tamanho e morfoecogenicidade do corpo lúteo detectados pelo ultra-som e os teores de progesterona plasmática em receptoras de embriões eqüinos?. Braz J Vet Res An Sci 2001; 38(5):233-239.https:// www.revistas.usp.br/bjvras/article/view/5877/7408

Azevedo MV, Souza NM, Ferreira-Silva JC, Batista IO, Moura MT, Oliveira MA, Oliveira MAL, Lima PF. Induction of multiple ovulations in mares using low doses of GnRH agonist Deslorelin Acetate at 48 hours after luteolysis. Pferdeheilkunde 2015; 31:160-164. www.hippiatrika.com/download.htm?id=20150208

Azevedo MV, Souza NM, Ferreira-Silva JC, Batista IO, Sales FABM, Alvarenga MA,Oliveira MAL, Lima PF. Indução de ovulações duplas utilizando baixa dose de deslorelina em éguas. Ciênc Vet Tróp 2014; 17 (1/2):42-47. http://revistas.bvs-vet.org. $\mathrm{br} / \mathrm{cvt} / \mathrm{article} / \mathrm{view} / 28811$

Bertani GR, Scheid IR, Fialho FB, Rubin MIB, Wentz I, Goncalves PBD. Effect of the time of artificial insemination with frozen- thawed or fresh semen on embryo viability and early pregnancy rate in gilts. Theriogenology 1997; 48(6):933-945. https://www. sciencedirect.com/science/article/pii/S0093691X9700321X

Betteridge KJ. Comparative aspects of equine embryonic development. Anim Reprod Sci 2000; 60:691-702. https://ac.elscdn.com/S0378432000000750/1-s2.0-S0378432000000750main.pdf?_tid=b8214fdf-1423-4854-9064-cb20cc46e2cd\&acd nat=1522156136_0d8c17138a5e1ac99fee76ae74fcb703

Claes A, Galli C, Colleoni S, Necchi D, Lazzari G, Deelen C, Beitsma M, Stout T. Factors influencing oocyte recovery and invitro production of equine embryos in a commercial OPU/ICSI program. J Equine Vet Sci 2016; 41:68-69. http://www.j-evs.com/ article/S0737-0806(16)30179-4/fulltext

Conley AJ. Review of the reproductive endocrinology of the pregnant and parturient mare. Theriogenology 2016; 86(1):355-365. http://www.theriojournal.com/article/S0093$691 X(16) 30088-7 / p d f$

Cuervo-Arango J, Aguilar J, Newcombe JR. Effect of type of semen, time of insemination relative to ovulation and embryo transfer on early equine embryonic vesicle growth as determined by ultrasound. Theriogenology 2009; 71(8):1267-1275. http:// www.theriojournal.com/article/S0093-691X(09)00019-3/pdf

Douglas RH. Some aspects of equine embryo transfer. J Reprod Fertil 1981; 32(S1): 405- 408. http://europepmc.org/abstract/ $\mathrm{med} / 6962874$

Duchamp G, Bour B, Combarnous Y, Palmer E. Alternative solutions to hCG induction of ovulation in the mare. J Reprod Fertil 1986; 35(S1):221-228. https://www.ncbi.nlm.nih.gov/ pubmed/3479577

Farias LD, Neves AP, Rechsteiner SMDEF, Tarouco AK. Indução da ovulação em éguas: uma revisão. Rev Bras Reprod Anim 2016; 40(1):17-21. http://cbra.org.br/pages/publicacoes/rbra/v40/n1/ p17-21\%20(RB611).pdf

Fleury JJ, Alvarenga MA. Effects of collection day on embryo recovery and pregnancy rates in a nonsurgical equine embryo transfer program. Theriogenology 1999; 51(1):261. http://www. theriojournal.com/article/S0093-691X(99)91820-4/pdf

Fleury JJ, Pinto AJ, Marques A, Lima CG, Arruda RP. Fatores que afetam a recuperação embrionária e os índices de prenhez após transferência transcervical em eqüinos da raça Mangalarga. Braz J Vet Res An Sci 2001; 38(1):29-33. https://www.revistas. usp.br/bjvras/article/view/5915/7446

Gibson C, Ruijter-Villani M, Stout TA. Negative uterine asynchrony retards early equine conceptus development and upregulation of placental imprinted genes. Placenta 2017; 57:175-182. http://www.placentajournal.org/article/S01434004(17)30656-2/pdf

Hajčić B, Samardžija M, Grizelj J, Dobranić T, Getz I, Prvanović N. Embryo transfer in mares. Vet Stanica 2008; 39(6):335-348. http://bib.irb.hr/prikazi-rad?rad=380659

Henneke DR; Potter GD; Kreider JL; Yeates BF. Relationship between condition score, physical measurements and body fat 
percentage in mares. Equine Vet J 1983; 15(4):371-372. https:// onlinelibrary.wiley.com/doi/pdf/10.1111/j.2042-3306.1983. tb01826.x

Hinrichs K. Assisted reproduction techniques in the horse. Reprod Fertil Dev 2012; 25(1):80-93. http://www.publish.csiro.au/rd/ RD12263

Imel KJ; Squires EL; Elsden RP; Shideler RK. Collection and transfer of equine embryos. J Am Vet Med Assoc 1981; 179(10):987-991. http://europepmc.org/abstract/med/7341563

Irvine $\mathrm{CH}$, Alexander SL, McKinnon AO. Reproductive hormone profiles in mares during the autumn transition as determined by collection of jugular blood at $6 \mathrm{~h}$ intervals throughout ovulatory and anovulatory cycles. J Reprod Fertil 2000; 118(1):101-109. http://www.reproduction-online.org/content/118/1/101.full.pdf

Iuliano MF, Squires EL, Cook VM. Effect of age of equine embryos and method of transfer on pregnancy rate. J Anim Sci 1985; 60(1):258-263. https://pdfs.semanticscholar. org/4cfe/643c0ced98947fddbb3aac548585f44ad6d9.pdf

Lira RA, Peixoto GCX, Silva AR. Transferência de embrião em equinos: revisão. Acta Vet Brasilica 2009; 3(4):132-140. https:// periodicos.ufersa.edu.br/index.php/acta/article/view/1421/782

McKinnon AO, Nobelius AM, Figueroa S, Skidmore J, Vasey JR, Trigg TE. Predictable ovulation in mares treated with an implant of the GnRH analogue deslorelin. Equine Vet J 1993; 25(4):321-323. https://onlinelibrary.wiley.com/doi/ pdf/10.1111/j.2042-3306.1993.tb02972.x

McKinnon AO, Squires EL. Equine embryo transfer. Vet Clin North Am Equine Pract 1988; 4(2):305-333. https://www.sciencedirect. com/science/article/pii/S0749073917306430?via\%3Dihub

Montechiesi DF. Transferência de embriões em equinos e os fatores relacionados as taxas de prenhez. Ciênc Anim 2015; 25(1):187-194. http://www.uece.br/cienciaanimal/dmdocuments/ palestra15_p187_194.pdf

Oguri N, Tsutsumi Y. Non-surgical recovery of equine eggs, and an attempt at non surgical egg transfer in horses. J Reprod Infertil 1972; 31(2):187-195. http://www.reproduction-online. org/content/31/2/187.full.pdf + html

Preacher KJ (2001). Calculation for the chi-square test: An interactive calculation tool for chi-square tests of goodness of fit and independence [software].

Rabelo MC, Taveiros AW, Melo PRM, Chaves RM, Santos Junior ER, Aguiar Filho CR, Bezerra FQG, Almeida-Irmão JM, Freitas Neto LM, Lima PF, Oliveira MAL. Taxas de prenhez e de perda embrionária em éguas da raça Mangalarga Marchador em diferentes status reprodutivos utilizadas como receptoras em programas de transferência de embriões. Med Vet (UFRPE) 2009; 3(4):13-19. http://www.ead.codai.ufrpe.br/index.php/ medicinaveterinaria/article/view/656/535

Rua MAS, Quirino CR, Pacheco A, Júnior AB, Vega HO, Ribeiro MDS. Follicular aspiration, in vitro maturation and intracytoplasmic injection in mares. PUBVET 2016; 10(3):248256. https://www.cabdirect.org/cabdirect/abstract/20163103862
Sanchez R, Herrera C, Blanco M, Rosati I, Lazzari G, Colleoni S, Sieme H, Galli C. In Vitro Production of Equine Embryos by Ovum Pick Up and Intracytoplasmic Sperm Injection in Young Mares. J Equine Vet Sci 2016; 41:77. http://www.j-evs.com/ article/S0737-0806(16)30198-8/fulltext

Sieme H, Sieme, H, Rau J, Tiedemann D, Oldenhof H, Barros L, Sanchez R, Blanco M, Martinsson G, Herrera C, Burger D. Equine Embryo Transfer. In: Animal Biotechnology 1. Springer 2018;179-192. https://doi.org/10.1007/978-3-319-92327-7_8

Squires EL, McCue PM. Vanderwall DK. The current status of equine embryo transfer. Theriogenology 1999; 51:91-104. http:// www.theriojournal.com/article/S0093-691X(98)00234-9/pdf

Squires EL. Use of progestins in open and pregnant mares. Anim Reprod Sci 1993; 33(14):183-193. https://www.sciencedirect. com/science/article/pii/0378432093901147

Stout TAE. Equine embryo transfer: review of developing potential. Equine Vet J 2006; 38(5):467-478. https://onlinelibrary. wiley.com/doi/abs/10.2746/042516406778400529

Stout TAE, Meadows S, Allen WR. Stage-specific formation of the equine blastocyst capsule is instrumental to hatching and to embryonic survival in vivo. Anim Reprod Sci 2005; 87(34):269-281. https://ac.els-cdn.com/S0378432004002532/1-s2.0S0378432004002532-main.pdf?_tid=220d09a5-db36-4d79-af3180b00c09cd5a\&acdnat $=1522159334 \_0761 d 5 d 3 a 73277$ ec2ba 1 ef226f01f157

Taveiros AW, Melo PRM, Freitas Neto LM, Aguiar Filho CR, Silva ACJ, Lima PF, Oliveira MAL. Produção de embriões de éguas Mangalarga Marchador utilizadas nas Regiões Nordeste e Sudeste do Brasil. Med Vet (UFRPE) 2008; 2(3):19-24. http:// www.journals.ufrpe.br/index.php/medicinaveterinaria/article/ view/687/566

Taveiros AW, Oliveira MA, Lima PF, Tenório FF, Bartolomeu CC, Santos MHB, Oliveira LR, Iunes-Souza TC, Freitas JC. Ultrasonographic monitoring of 103 recipient mares of different reproductive status during the first 30 days after embryo transfers. Vet Rec 2003; 153(18):558-560. https://www.ncbi.nlm.nih.gov/ pubmed/14627236

Vanderwall DK. Early embryonic loss in the mare. J Equine Vet Sci 2008; 28(11):691- 702. http://www.j-evs.com/article/S07370806(08)00331-6/abstract

Vogelsang SG, Bondioli KR, Massey JM. Commercial application of equine embryo transfer. Equine Vet J 1985; 17(S3):89-91. https:// onlinelibrary.wiley.com/doi/pdf/10.1111/j.2042-3306.1985. tb04603.x

Weber JA, Freeman DA, Vanderwall DK, Woods GL. Prostaglandin E2 hastens oviductal transport of equine embryos. Biol Reprod 1991; 45(4):544-546. https://academic.oup.com/biolreprod/ article/45/4/544/2763008

Wilson JM, Rowley MB, Rowley WK, Smith HA, Webb RL, Tolleson DR. Successful non-surgical transfer of equine embryos to post-partum lactating mares. Theriogenology 1987; 27(1):295. http://www.theriojournal.com/article/0093-691X(87)90172-5/pdf 